Marquette University

e-Publications@Marquette

$1-1-2012$

\title{
Stakeholder Theory and Marketing: Moving from a Firm-Centric to a Societal Perspective
}

Gene R. Laczniak

Marquette University, eugene.laczniak@marquette.edu

Patrick E. Murphy

University of Notre Dame

Published version. Journal of Public Policy \& Marketing, Vol. 31, No. 2 (2012): 284-292. DOI. (C) 2012, American Marketing Association. Used with permission. 


\title{
Stakeholder Theory and Marketing: Moving from a Firm-Centric to a Societal Perspective
}

\author{
Gene R. Laczniak and Patrick E. Murphy
}

\begin{abstract}
This essay is inspired by the ideas and research examined in the special section on "Stakeholder Marketing" of the Journal of Public Policy \& Marketing in 2010. The authors argue that stakeholder marketing is slowly coalescing with the broader thinking that has occurred in the stakeholder management and ethics literature streams during the past quarter century. However, the predominant view of stakeholders that many marketers advocate is still primarily pragmatic and company centric. The position advanced herein is that stronger forms of stakeholder marketing that reflect more normative, macro/societal, and network-focused orientations are necessary. The authors briefly explain and justify these characteristics in the context of the growing "prosociety" and "proenvironment" perspectives-orientations that are also in keeping with the public policy focus of this journal. Under the "hard form" of stakeholder theory, which the authors endorse, marketing managers must realize that serving stakeholders sometimes requires sacrificing maximum profits to mitigate outcomes that would inflict major damage on other stakeholders, especially society.
\end{abstract}

Keywords: stakeholders, marketing ethics, stakeholder theory, normative ethical theory, societal marketing concept, social responsibility

S takeholder theory has finally moved "front and center" in the academic marketing literature. Bhattacharya (2010), inspired by his prior analysis on the promise of an enlightened stakeholder perspective (Bhattacharya and Korschun 2008), edited the special section on "Stakeholder Marketing" in a recent issue of Journal of Public Policy \& Marketing $(J P P \& M)$. The section features ten articles that include conceptual models, empirical reports, implementation schemes, and essays on various aspects of stakeholdercentric marketing. Bhattacharya remarks (p. 1, emphasis added) that "recent realities such as climate change, obesity crises, and human rights violations ... are prompting companies to look beyond customers as the sole target of marketing activities and firms as the primary intended beneficiary.... [T] adopts a broader and more inclusive stakeholder orientation." For marketers even tangentially interested in stakeholder issues, this assembly of articles is essential reading.

Yet, as we explain in this essay, a hidden and socially important dimension to this "more inclusive" stakeholder theory also exists, which, if accepted in its stronger manifestations - what we call its "hard form"- has far-reaching

Gene R. Laczniak is Professor of Marketing, Department of Marketing, Marquette University (e-mail: Eugene.Laczniak@marquette. edu). Patrick E. Murphy is Professor of Marketing, Mendoza College of Business, University of Notre Dame (e-mail: Murphy.72@nd.edu). The authors sincerely thank the anonymous reviewer for insightful comments and suggestions that greatly improved this commentary. implications for the assessment of marketing practice. This robust form of stakeholder theory was only hinted at in the anthology of articles published in the special section on "Stakeholder Marketing." We also try to put into perspective the evolution of stakeholder theory in management and business ethics circles, beginning with Freeman (1984), and its implications for the study and practice of marketing in the future. Subsequently, we propose a variation of hardform stakeholder theory, which suggests that in addition to being agents for the company's owners and advocates for consumer satisfaction, marketing managers need to consider themselves stewards for a better society.

Marketers are relative latecomers to the stakeholder perspective. According to Freeman's (1984, p. 46) seminal definition, stakeholders consist of "any group or individual who can affect or is affected by the achievement of an organization's objectives." The management literature has published hundreds of articles and dozens of books on the importance and centrality of a stakeholder perspective since the mid-1980s (for a discussion of marketing coverage in several insightful management books about our topic, see Table 1). Marketers have an understandable disposition to examine the business environment through a customized lens - that is, the effects of their value propositions on customers and how that formulation affects the financial position of the firm. The relative invisibility of hard-form stakeholder orientation in marketing, until recently, is likely due to the traditional goal of marketing practitioners to make prominent (at least in principle) the concerns of customers. Such thinking is captured in the notion of the hoary "marketing concept" as well as the 
Table 1. Marketing and Normative Coverage in Stakeholder Books

\begin{tabular}{|c|c|c|c|}
\hline Author & Year & Marketing Coverage & Normative Ethical Foundation \\
\hline Freeman & 1984 & $\begin{array}{l}\text { - Customers are one of four key stakeholders (pp. } \\
\text { 9-10). } \\
\text { - Public relations/affairs: Stakeholder approach (SA) } \\
\text { spreads the traditional public relations role among } \\
\text { all managers (pp. 219-22). } \\
\text { - Marketing managers: SA recognizes the different } \\
\text { types of marketing positions (sales, market } \\
\text { research). } \\
\text { - It is important for marketing managers to focus on } \\
\text { customers and competitors (pp. 226-28). }\end{array}$ & $\begin{array}{l}\text { Utilitarian Strategy } \\
\text { - Maximize benefits to all stakeholders (greatest } \\
\text { good for greatest number) } \\
\text { - Maximize average welfare level of all stakeholders } \\
\text { - Maximize benefits to society } \\
\text { Rawlsian Strategy } \\
\text { - Act to raise the level of the worst-off stakeholders }\end{array}$ \\
\hline Svendsen & 1998 & $\begin{array}{l}\text { - Customers are one of four major stakeholder } \\
\text { groups (pp. 21-27). Marketing is analyzed in build- } \\
\text { ing relationships with stakeholders (pp. 53-61). }\end{array}$ & $\begin{array}{l}\text { - Ethics examined in the context of corporate culture } \\
\text { and profitable operations }\end{array}$ \\
\hline $\begin{array}{l}\text { Post, Preston, } \\
\text { and Sachs }\end{array}$ & 2002 & $\begin{array}{l}\text { - Customers and users are considered stakeholders } \\
\text { (p. 22). } \\
\text { - Supply chain associates are also included as stake- } \\
\text { holders (p. 49). } \\
\text { - Customer stakeholders are explained in China } \\
\text { example (pp. 184-86). }\end{array}$ & $\begin{array}{l}\text { - Organizational morality forms the normative } \\
\text { "core" of the stakeholder model: Legitimate stake- } \\
\text { holder interests require managerial recognition and } \\
\text { attention as a matter of moral right. }\end{array}$ \\
\hline Phillips & 2003 & $\begin{array}{l}\text { - Customers are noted as stakeholders in several } \\
\text { places (pp. 133, 158, 162, 166). }\end{array}$ & $\begin{array}{l}\text { - Stakeholder fairness is based on Rawls's (1971) } \\
\text { principle of fair play as a moral foundation of } \\
\text { stakeholder theory, including mutual benefit, jus- } \\
\text { tice, and cooperation. }\end{array}$ \\
\hline $\begin{array}{l}\text { Freeman, } \\
\text { Harrison, } \\
\text { and Wicks }\end{array}$ & 2007 & $\begin{array}{l}\text { - Principle } 8 \text { (of 10): We need to generalize the mar- } \\
\text { keting approach (pp. 57-58). } \\
\text { - Customers are viewed as stakeholders throughout. } \\
\text { - Marketing examples of customer stakeholders: } \\
\text { Grameen Bank, Wal-Mart, and Whole Foods. }\end{array}$ & $\begin{array}{l}\text { - Ethics and values questions are at the core of } \\
\text { Managing for Stakeholders because executives } \\
\text { early on in the process must determine which } \\
\text { stakeholders they are creating value for. Both the } \\
\text { traditional value chain and the responsibility chain } \\
\text { are discussed. }\end{array}$ \\
\hline Freeman et al. & 2010 & $\begin{array}{l}\text { - Recent literature on stakeholder theory in market- } \\
\text { ing was reviewed, and examples featured in Firms } \\
\text { of Endearment (Sheth, Sisodia, and Wolfe 2007) } \\
\text { were discussed. }\end{array}$ & $\begin{array}{l}\text { - Stakeholder theory in marketing specifically } \\
\text { mentioned virtues, such as trust, responsibility, } \\
\text { and commitment, as foundations for relationship } \\
\text { marketing. }\end{array}$ \\
\hline
\end{tabular}

strategic intent of "relationship marketing" (Berry 1995; Drucker 1954). According to such views, customers are the particular stakeholder group to be elevated to the prime position of concern in a marketing-driven organization.

In the featured conceptual article of the "Stakeholder Marketing" special section, Smith, Drumwright, and Gentile (2010) correctly portray the consumer-centric orientation of too many marketing firms as "the new marketing myopia." Such single-minded companies view consumers as "a commercial entity seeking to satisfy short-term, material needs through consumption behaviors" (p. 4). Certainly, such observations resonate with many readers of $J P P \& M$. For example, tobacco marketing, the selling of "pay-day" loans, and the promotion of sugared soft drinks all produce some initially satisfied consumers, along with troubling and exploitive secondary effects for the rest of society. Thus, Smith, Drumwright, and Gentile insightfully note that "when marketers give insufficient attention to stakeholders, they do so at great peril; their customers, their companies, and society at-large likely will be adversely affected" (p. 5). The failed marketing promises of easy consumer credit, effortless weight reduction, ever-rising home prices, and cheap energy are recent testimony to the pub- lic's disenchantment with the misleading promotional enticements of many marketers.

Smith, Drumwright, and Gentile (2010) go on to offer five helpful guiding propositions to counter this new marketing myopia in business firms: (1) mapping company stakeholders, (2) determining their salience, (3) researching stakeholder expectations, (4) engaging with stakeholders, and (5) embedding a stakeholder orientation in the marketing process. Granting that most marketing academics came late to the stakeholder perspective, such propositions are similar to those that Laczniak and Murphy (1993, p. 51) postulated earlier as "the essence of appropriate ethical decisionmaking" for all marketing organizations. Here, they recommend the strategic and societal benefits of (1) delineating who the stakeholders are, (2) determining what primary or secondary stakes each group holds in the organization, (3) establishing what responsibilities the organization has to each stakeholder group, and (4) deciding on a planned strategy to balance the conflicts among stakeholder claims (p. 16). In further work, Laczniak and Murphy (2006), in reviewing 50 years of writings on normative marketing ethics, designate "embracing the stakeholder concept" as one of seven abiding 
propositions for socially responsible marketing. Specifically, "the adoption of a stakeholder orientation is essential to the advancement and maintenance of ethical decision-making in all marketing operations" (p. 167). Thus, long-standing recognition of the need for greater marketing attention to all stakeholders exists, but it has gone mostly unheard or unheeded in the strategic marketing literature.

Our assessment of this special $J P P \& M$ stakeholder compilation finds many thoughtful and important contributions to marketing thinking. As long-time readers of the marketing and society literature, we believe that this corpus of work is impressive and (hopefully) will inspire further research in stakeholder marketing. For readers interested in the topic of stakeholders and marketing, this special section is an essential checkpoint. Although every article plays its part in the success of expanding stakeholder marketing, we are particularly encouraged by the rich strategic implications of the following:

- Using an investment game simulation with a sample of practicing managers, Martin and Johnson (2010) find that some managers will attempt to leverage "positive" stakeholder treatment in the supply chain with their customers even if they cannot verify that ethical treatment in the sourcing network is really occurring. This suggests that among some marketers, stakeholder attention is being leveraged for instrumental purposes.

- Ingenbleek and Immink (2010), building on the management writing of Mitchell, Agle, and Wood (1997), carefully examine four case studies involving significant stakeholder interactions by Netherlands-based companies; they conclude that power of the stakeholder and urgency of the issue both determine the degree to which any particular stakeholder will be accommodated in shaping a company's corporate social responsibility strategy-a sort of "squeaky-wheel" finding that also indicates that stakeholder orientation may be "forced" on some organizations more by necessity than by philosophy.

- Raghubir et al. (2010) begin the important task of specifying the outcome measures that could be used to evaluate a firm's actual impact on stakeholder well-being; especially notable are their suggested possibilities for better judging the well-being and quality of life of external stakeholders (e.g., the community).

Those who advocate that marketing academics have a special responsibility to examine the connections of marketing activities with the broader society should particularly welcome this emergent work (Wilkie and Moore 2003, 2006). Although the use of the term "stakeholder" in a commercial context goes back to Colonial times (Calton and Payne 2003), when it ratified that property ownership granted a person a special "stake" in the affairs of the community, the academic roots of stakeholder theory derive from Freeman's (1984) seminal book. Freeman formulated his notion of the stakeholder approach as an enlightened but instrumental outlook that likely would lead to better longterm performance by firms that attempted to explicitly manage their various stakeholders (e.g., owners, employees, customers, suppliers, distributors, host community). Over time, this original conception evolved as the "stakeholder management" perspective, in which the firm develops strategies to manage the rights and claims of various stakeholders for the purpose of creating more effective organizational strategy.

Today, the most common approach to stakeholders in marketing circles is predominantly instrumental and com- pany centric. Stakeholders are "analyzed" so that their claims can be managed in a way that does not trump the economic imperatives of the firm. Emblematic of this traditional approach are the many "hub-and-spoke" diagrams that depict the firm at the center of a wheel of stakeholder influences (Rowley 1997). Various stakeholders are then identified for the purpose of being managed by contract, negotiation, public relations, lobbying, placation, intimidation, or litigation. In effect, for many companies mouthing this "soft form" of stakeholder management, its rationale is an appreciated perspective only because it can work to the benefit of corporate managers or shareholders by helping maximize profit. Manifestations of this dominant soft form of stakeholder theory can be deduced in the article excerpts of the special section of $J P P \& M$, which we describe next. The quotations we include are selected not to suggest that the authors endorse soft-form stakeholder theory for marketing strategy but rather to underscore its pervasive reality. Consider the following excerpts and their distinct appeals to the firm's economic advantage as the primary payoff for stakeholder concern:

- After reporting on the inspiring stakeholder orientations of several (smaller) privately held firms, Mish and Scammon (2010) discuss the considerable challenge of implementing any of these in publicly held companies: "To succeed in overcoming the obstacles to pursuing principle-based stakeholder marketing, managers of existing single-bottom-line public firms must focus on a long-term systems perspective, especially when short-term marketing demands seem most pressing" (p. 24). In other words, many smaller organizations begin with an operating philosophy that attempts to duly consider the claims of every stakeholder - a point of view essential to hardform stakeholder theory. As these firms grow and become more successful, however, some "go public," and the demands of their many impersonal investors to maximize short-term shareholder returns lead to a change in philosophy in which other stakeholder claims become marginalized.

- Hoeffler, Bloom, and Keller (2010) argue compellingly for the stakeholder orientation embedded in corporate citizenship initiatives and offer helpful strategic advice in this regard. However, their justifying rationale seems tightly linked to the firm-centric and brand enhancement outcomes of such efforts: "Firms spend considerable sums of money to promote their reputations and their brands in an effort to enhance their fortunes in the marketplace. We believe that firms can improve the effectiveness of these efforts by devoting a larger proportion of their budgets to [corporate citizenship] initiatives" (p. 87). In other words, being perceived as a good public citizen is the ticket to improved brand and corporate perceptions. Indicative of such instrumental approaches are the many corporate speeches, such as that by the chief executive officer of Dow Chemical (Liveris 2010), circulating on the business landscape.

- Ferrell et al. (2010) insightfully remark that companies' typical market orientation (MO) on customers and competitors may be at odds with the broader scope and responsibilities of stakeholder orientation (SO): "In some firms, MO and SO may lead to a similar marketing strategy, but in other firms, there may be significant differences" (p.95). They go on to note that at least some of the time, an overlapping sweet spot between the two approaches can be found because "the bonds of identification stimulated by SO translate into increased resources (e.g., employee commitment, good reputation) and, in turn, into enhanced business performance" (p. 
95). We agree with Ferrell et al. but are not as optimistic about marketer-conceived stakeholder orientations typically aligning corporate goals (market orientation) with the best long-term interests of all stakeholders.

We enthusiastically applaud the situations in which greater attention to multiple stakeholders leads to higher company profits. An article in Strategic Management Journal (Godfrey, Merrill, and Hansen 2009), based on the analysis of 160 firms over a ten-year period, cautiously suggests that firms that invest in secondary stakeholders financially outperform those that focus more directly on trading partners (i.e., customers) and their shareholders. This is consistent with progressive views in the marketing literature that marketers need to embrace business and society (Sheth, Sisodia, and Wolfe 2007). Note, however, that this instrumental, soft form of stakeholder theory (Jones 1995), though helpful at times to both firms and society, is quite different from the hard form of stakeholder theory increasingly being advocated in much of the management literature (Clarkson 1995; Waddock 2005). Bhattacharya (2010, p. 1) hints at this dichotomy when he remarks that "[stakeholder marketing] is not necessarily at odds with shareholder value maximization."

The implication here is that, oftentimes, a stakeholder orientation is directly and necessarily in opposition to higher shareholder profits. Respecting the claims of stakeholders is often precisely at odds with a company's financial interests, as BP painfully discovered with its $\$ 20$ billion escrow fund, established under intense public pressure during the catastrophic oil spill in the Gulf of Mexico (Wilson and Achenbach 2010). Similarly, Toyota resisted widespread product recalls, until mandated by the U.S. Federal government, despite mounting evidence that a cluster of problems was occurring from the "sudden acceleration" of its vehicles (Isidore 2010). If the recall had been implemented with a hard-form mind-set that it was imperative to protect all stakeholders, the loss of tens of millions of dollars in Toyota profits would likely have been avoided as well as the deterioration of considerable brand equity and market share. That crumpling floor mats rather than defective parts may have been the real problem did not excuse Toyota's reluctance to respond. Johnson \& Johnson, which has long espoused and been credited for its stakeholder orientation through its famous Credo, has recently conducted "phantom recalls" and been forced by the Food and Drug Administration to implement several other recalls during the past two years (Blanton et al. 2011; Olaniran et al. 2012). Not only is Johnson \& Johnson acting irresponsibly toward its designated stakeholders (i.e., customers, employees, communities, and stockholders), but it has also badly tarnished its long-honed reputation for hard-form stakeholder thinking that its people-oriented handling of the Tylenol recalls in the 1980s helped vitalize.

\section{Normative, Macro, and Network-Focused Stakeholder Marketing}

Stakeholder marketing, if accepted along the progressive dimensions being discussed in much of the current academic management literature (Elms et al. 2010), represents a radical, and we would argue socially beneficial, revision of how most marketing practitioners currently perceive the purpose of their firms with respect to stakeholders. We contend that marketers need to internalize three characteristics of hard-form stakeholder theory: (1) that it is normative and aspirational in its ethical standards, (2) that it raises questions about the conduct of marketing that are fundamentally macro in nature rather than firm centric, and (3) that it prescribes greater engagement with external stakeholder networks rather than exclusively focusing on customer concerns within the exchange process.

\section{Hard-Form Stakeholder Theory's Normative Ethical Aspirations}

By "normative ethical," we mean that hard-form stakeholder theory implies a duty-based moral mandate that must be embraced regardless of whether its outcomes are financially favorable to the firm. This moral imperative requires that marketers delineate and be responsible for the negative societal outcomes of their actions on all stakeholders.

From its inception, the theory of stakeholders was perceived (among its other dimensions) as being normative, rooted in the recognition of the ethical claims by various parties (i.e., stakeholders) that needed to be addressed rather than being primarily a tool for the efficient management of business. In referencing Rawls (1971), Freeman (1984) notes that all parties influenced by the actions of a firm have moral and legal claims, anchored in justice, not to be negatively affected by firm-caused externalities that these stakeholders have not engendered. Stated positively, all firms have an unwavering ethical obligation to attend to the claims of affected parties (e.g., employees, customers, suppliers, the host community), insofar as the company negatively influenced or benefited from actions affecting those stakeholders.

Research perhaps best documenting the normative ethical obligations of managers is the comprehensive literature analysis by Donaldson and Preston (1995), who trace the history of the various dimensions of stakeholder theory. They find that the body of stakeholder writings has four elements: First, it is descriptive because stakeholder writings define the constellation of parties possibly affected by business operations. Second, stakeholder theory is managerial because it can be used as an organizing framework to allocate the firm's attention to its various constituencies. Third, it is instrumental because the firm's scrupulous attention to stakeholders should often lead to better financial outcomes. Fourth, and most important, it is normative because it helps define the idealized purpose of the firm (Evan and Freeman 1988). Donaldson and Preston (1995, p. 88) place the normative dimension of stakeholder theory at the core of their conceptualization and conclude that "the ultimate justification for the stakeholder theory is to be found in its normative base. The plain truth is that the most prominent alternative to the stakeholder theory (i.e., the "management serving the shareholders' theory) is morally untenable."

Ironically, the father of stakeholder theory, Edward Freeman, has argued with himself about the extent to which a stakeholder orientation can be viewed as instrumental for managerial performance, in contrast with a normative ethical mandate. Perhaps bowing to the harsh reality that the majority of corporations embrace stakeholder thinking only 
when it is to their economic advantage, Freeman (1999) gravitates to a modified instrumental stakeholder thesis, which advocates always paying attention to key stakeholder relationships because doing so maximizes shareholder value over an extended period. Less than a decade later, however, some backpedaling has occurred; Freeman, Harrison, and Wicks (2007) argue that ethics and values questions are at the core of managing for the betterment of stakeholders (p. 11) and that "if managers try to maximize the interests of any one stakeholder, they will run into trouble" (p. 157).

The implications for marketing academics and researchers interested in stakeholder theory need to be underscored. Because marketing has historically been focused on profitably overseeing the value chain, with exchange as its common denominator, an overriding normative ethical question for marketing typically involves issues of distributive justice (Laczniak and Murphy 2008). This standard is normative because it attempts to evaluate the fairness and efficiency of market transactions. That is, for each market system or exchange relationship, marketing academics should adjudicate whether the benefits and burdens of the economic transactions are fairly shared among all stakeholders. For example, applied to broader conceptions of stakeholder theory, marketers should ask the following questions: Are any stakeholders being unfairly or unjustly affected by marketing activities? Are their ethical and legal claims being recognized, discussed, and addressed by the marketing organization? For marketing managers who profess that ethical concerns are central to the building of trust among stakeholders, it is these questions that require greater reflection and that ultimately shape how microlevel transactions in particular market segments should be assessed from a macro, public policy standpoint. This ethical restatement of stakeholder orientation, rooted in a normative, ethical standard of distributive justice, leads to the observation discussed in the following subsection.

\section{Hard-Form Stakeholder Theory's Macro (Marketing System) Questions and Micro (Firm-Centric) Strategy}

Hard-form stakeholder theory suggests that the purpose of the business organization is broader than simply customer satisfaction at the firm level or wealth maximization for company shareholders. Understandably, both these elements are (and should be) part of the guiding doctrine of almost all marketing firms. However, the purpose of business (writ large), from the standpoint of stakeholder theory, goes beyond the microfirm level and is collectively intended to help promote the greater common good of the stakeholder network. According to hard-form stakeholder theory, the creation of "value" by the firm is to be understood broadly and socially, not merely from the customer and shareholder perspectives (Freeman, Wicks, and Parmar 2004).

Since the mid-1970s, the macro aspects of marketing systems and the social contract from which all marketing firms derive their legitimacy have not been adequately discussed in the mainstream marketing literature (Wilkie and Moore 2006). Though beyond the scope of this essay, a sketch of the rationale underlying the social contract goes something like this: Complex economic exchange is necessary for societies to flourish and for individuals to achieve their full potential. Therefore, the aggregate market economy should always be primarily in the service of people, helping them live ever-fuller lives. This implies the acceptance of an authentic stakeholder empathy that arises from the understood solidarity of people and the global communities in which they reside. The "common good" is always a somewhat subjective matter, but economic growth is clearly only one factor in a community well-being that includes familial, social, aesthetic, and cultural developments and achievements. If economic maximization is not the end goal, neither is profit maximization. Profit is a means to an end, a reward for risk undertaken by marketers who provide the goods and services that society needs. Profit should be a byproduct of a commercial transaction well done (Handy 2002). The opportunity to secure this possible reward by providing market-based needs is one-half the "social contract" that firms have with the community. The other half is the responsibility of firms to operate in an ethical and socially accountable manner to repay the societal-grounded license for individual economic profit.

Bhattacharya (2010), in one of the limited forays into macrolevel thinking in the JPP\&M special section, recognizes communal value creation explicitly and insightfully in his postulated model of stakeholder business strategy. In that model, his measured (stakeholder) outputs are not only probusiness but also prosocial and proenvironmental; that is, such outcomes seemingly conform to the so-called triple bottom line (Elkington 1998). Such hard-form conceptions of stakeholder theory imply that marketing managers are not only agents for company owners (i.e., profit orientation) but also stewards for society, with a professional responsibility to take a societal perspective (i.e., people and planet) when assessing the likely externalities of their selected marketing strategies on stakeholders. In other words, hard-form stakeholder theory is an emergent alternative to the traditional purpose of the firm being predominantly to maximize profit at the company level. Instead, it conceives of the purpose of a responsible marketing firm as earning a competitive return on investment for shareholders, while always acting in an accountable and socially sustainable manner without causing damage to the physical environment or the social exploitation of stakeholders.

This tenet is well reflected in conceptions of stakeholder theory commonly found in the management literature. For example, Donna Wood (qtd. in Agle et al. 2008, p. 160) positions stakeholder theory as an alternative to the untenable assumptions of neoclassical economic theory: "Institutions do not exist to serve their own purposes, but rather to serve the needs of societies and peoples." Thomas Donaldson (also in Agle et al. 2008) predicts a "normative revolution" that broadens the thinking of corporations about their responsibilities, is inspired directly by stakeholder theory, and is rooted in the recognition that a stakeholder orientation fundamentally captures the idea that all human beings (affected by business) have intrinsic worth.

The recent global Great Recession is testimony to the notion that unit-maximizing, unregulated enterprise does not always produce the stable and efficient markets predicted by previously unquestioned economic models 
(Stiglitz 2010). Hard-form stakeholder theory demands that marketers accept a broader and deeper view of their societal mandate. Understandably, some skeptics doubt that marketers will ever give up their soft-form, often selfserving view of stakeholder theory without regulation (Marens 2010). Regardless of the best way to proceed, this macro dimension of hard-form stakeholder orientation augurs greater examination in academic marketing research, especially by those interested in public policy questions.

\section{Hard-Form Stakeholder Theory's Cocreative Engagement with a Firm's Stakeholder Network}

During the 1990s, as marketing firms began to co-opt the language of stakeholder theory, the acceptance of this concept was extremely instrumental and pragmatic. If (stakeholder) employees were well satisfied, they would treat customers better; if (stakeholder) suppliers were dealt with fairly, buyers would feel better about their purchases; if the (stakeholder) community was partnered with, consumers would develop greater brand loyalty. Much of the time, soft-form stakeholder theory is economically useful. In such instances, the motivation for accepting stakeholder theory is conditional on it improving the bottom line. In contrast, even the earliest management theory stakeholder conceptions could be viewed as positioning stakeholders as partners with a fair voice in company decisions, drawing on the writing of Rawls (1971; see Freeman 1984) and later with an emphasis on absolute duties from a Kantian perspective (Evan and Freeman 1988).

A shift in perceptions of a few marketers may first have been noted by Maignan, Ferrell, and Ferrell (2005, p. 974), who wrote, "Marketing is moving from a narrow customer orientation to managing relationships and benefits for all stakeholders." Within the context of this observation, the idea of cocreation, as espoused in the service-dominant logic (Vargo and Lusch 2004), is cited with approval. Now, in the twenty-first century, the academic literature increasingly portrays stakeholders not simply as conditional to but also as essential for a process of external engagement (Jawahar and McLaughlin 2001; Phillips 2003; Waddock 2005). Hard-form stakeholder theory engages with each stakeholder group through a demonstrable process for ongoing dialogue (Andriof and Waddock 2002). Books such as Managing for Stakeholders (Freeman, Harrison, and Wicks 2007) describe possible protocols for doing exactly this and giving various stakeholders additional voice.

As we previously suggested, the literature outside marketing management consistently reflects a broader view of stakeholder theory than the consumer-focused (and firmcentric) conceptions typically discussed in most stakeholder marketing articles, including the special section of $J P P \& M$. For example, Rowley (1997) suggests that stakeholder power is best understood not from a dyadic standpoint but rather by understanding the "density" of stakeholders and the firm's "centrality" within the relevant business network. Lindfelt and Törnroos (2006) contend that the networked view of firms, suppliers, distributors, and customers may be even more useful for envisioning a firm's core competen- cies than the traditional (dyadic) stakeholder approach. Furthermore, in a major review article on stakeholder theory, Laplume, Sonpar, and Litz (2008, p. 1152) advocate for "a return to the theory's emphasis on the strategic stakeholder management, albeit with a broader view of the firm's performance." Most recently and provocatively, Werhane (2012) suggests scrapping the hub-and-spoke model so endemic to soft-form stakeholder thinking and replacing it with a "complex adaptive system" in which the firm is not at the center of the diagram but rather is one among many interconnected social partners constituting the sociocommercial nexus.

The ramifications of this view are enormous because it implies accepting a stakeholder network view rather than marketing's traditional customer-focused orientation. Moreover, the analytic, research lens of hard-form stakeholder thinking is less firm centric and more societal, as embodied in the triple-bottom-line measurements of success already mentioned. Recent research dealing with the evolution of marketing strategy (Lusch and Webster 2011) perceives the expanded task of marketing as optimizing both the effectiveness and the efficiency of the entire marketing network by cocreating value with partners rather than simply focusing on the satisfaction of customers. "The firm must be understood as a complex network mechanism linking customer value and the value of the firm for all its stakeholders" (Lusch and Webster 2011, p. 131).

\section{Conclusion}

To summarize our thesis, the soft form of stakeholder theory, accepted by most marketing organizations and dominating much of the $J P P \& M$ special section, is highly instrumental and (micro) firm focused. In addition, stakeholder concerns are managed by marketers through one-onone (dyadic) negotiation and integrated (i.e., taken seriously) mainly if they project improved profitability in the short or medium term. Without doubt, expected investor returns and the satisfaction of customer needs are minimums for organizational survival. However, the hard form of stakeholder theory, which much of the management literature now endorses (Svendsen 1998), represents an increasingly evident paradigm shift because of its societal orientation-it is decidedly more ethically normative, macro, and network focused. Stakeholders are accorded enhanced voice (i.e., dialogic input embodied in company policies) to question marketing actions in a manner consistent with the service-dominant logic proposition of cocreation (Vargo and Lusch 2004, 2008) and consonant with proactive corporate social responsibility (i.e., addressing social concern quickly) (Elms et al. 2010). The goal of the hard-form approach is to fairly apportion the costs of externalities among the full network of stakeholders, thereby putting the creation of stakeholder benefit at the center of strategy consideration and as the reconstituted social purpose of marketing organizations (Svendsen and Laberge 2006).

The reality is that this hard form of stakeholder orientation will be vigorously resisted by many marketing firms because it does not exclusively focus on profit growth and 
maximization. Such reluctance is understandable, as is many corporations' refusal to amend the increasingly discredited "efficient market thesis" of unregulated competition and the "self-interest-maximizing" buyer rationality as the main pathways to economic insight. As we outline in this essay, the social ethos of expectations for business performance may be shifting. Indeed, a reasonable case can even be made for why marketers might welcome a set of globally uniform, ethical "hyper norms"-precisely because such norms would reduce managerial uncertainty about what constitutes the boundaries of acceptable corporate behavior with all stakeholders (Laczniak and Kennedy 2011).

We also predict that public policy considerations, conspicuously underanalyzed in the $J P P \& M$ special section, will become markedly more critical in helping understand and implement the hard form of stakeholder marketing. As business influence becomes increasingly global and economically powerful, society will demand greater responsibility and accountability for all its ramifications. In effect, public policy mechanisms and processes become the countervailing force to the natural resistance of marketing organizations to any paradigm shift, including a movement away from soft-form stakeholder orientation. In other words, as some organizations strive to protect the status quo of self-serving stakeholder "co-optation," numerous public policy adjustments will be demanded to ensure that the prosociety and proenvironmental dimensions of the triple bottom line are counted along with the usual probusiness metrics (Bhattacharya 2010). Practically speaking, this means that public policy debates about what exactly constitutes the societal common good and what social measurements reflect that progress will become prominent in the academic conversation on the organizational effectiveness and social fairness of marketing practices. In short, we predict a return to the neglected (and marginalized) "societal marketing concept," introduced by Philip Kotler in the 1970s and still included in his many textbooks (e.g., Kotler and Armstrong 2010). According to this view, marketing organizations should be monitored by institutions of national and international public policy enforcement, so that they will "deliver value to customers that maintains or improves the consumer's and society's well-being" (Kotler and Armstrong 2010, p. 11).

This approach is also in keeping with the American Marketing Association's definition of marketing, which delineates "society at large" as an important stakeholder (as Gundlach and Wilkie [2010] succinctly discuss in the special section). We look forward to future scholarly analysis that addresses stakeholder theory that not only builds on the excellent research presented in the $J P P \& M$ special section but also reflects the broader dimensions of stakeholder theory we discuss herein. Consistent with hard-form stakeholder thinking, we end with a strong endorsement of Mick's (2007, p. 291) characterization of marketing's macro, societal responsibilities:

If marketing is to live up to its maximum potential, simultaneously with its sociological obligation, and also become more genuinely appreciated by the public, the goal of marketing ... must be the common good.

\section{References}

Agle, Bradley R., Thomas Donaldson, R. Edward Freeman, Michael C. Jensen, Ronald K. Mitchell, Donna J. Wood, et al. (2008), "Dialogue: Toward Superior Stakeholder Theory," Business Ethics Quarterly, 18 (2), 153-90.

Andriof, J. and Sandra A. Waddock (2002), "Unfolding Stakeholder Engagement," in Unfolding Stakeholder Thinking: Theory, Responsibility and Engagement, J. Andriof, S.A. Waddock, B.W. Husted, and S.S. Rahman, eds. Sheffield, UK: Greenleaf, 19-42.

Berry, Lenard L. (1995), "Relationship Marketing of Services: Growing Interest, Emerging Perspectives," Journal of the Academy of Marketing Science, 23 (4), 236-45.

Bhattacharya, C.B. (2010), "Introduction to the Special Section on Stakeholder Marketing," Journal of Public Policy \& Marketing, 29 (Spring), 1-3.

— and Daniel Korschun (2008), "Stakeholder Marketing: Beyond the Four Ps and the Customer," Journal of Public Policy \& Marketing, 27 (Spring), 113-16.

Blanton, John, Catherine Larkin, Jef Feeley, and Margaret Cronin Fisk (2011), "Johnson \& Johnson Fights to Clear Its OnceTrusted Name," Bloomberg BusinessWeek, (April 4-10), 64-71.

Calton, Jerry M. and Steven L. Payne (2003), "Coping with Paradox: Multistakeholder Learning Dialogue as a Pluralist Sensemaking Process for Addressing Messy Problems," Business \& Society, 42 (1), 7-42.

Clarkson, Max B.E. (1995), “A Stakeholder Framework for Analyzing and Evaluating Corporate Social Performance," Academy of Management Review, 20 (1), 92-117.

Donaldson, Thomas and Lee E. Preston (1995), "The Stakeholder of the Corporation: Concepts, Evidence and Implications," Academy of Management Review, 20 (1), 65-91.

Drucker, Peter F. (1954), The Practice of Management. New York: Harper \& Row.

Elkington, John (1998), Cannibals with Forks: The Triple Bottom Line for 21 st Century Business. Gabriola Island, BC: New Society Publishers.

Elms, Heather, Stephen Brammer, Jared D. Harris, and Robert A. Phillips (2010), "New Directions in Strategic Management and Business Ethics," Business Ethics Quarterly, 20 (July), 401-425.

Evan, William M. and R. Edward Freeman (1988), "A Stakeholder Theory of the Modern Corporation: Kantian Capitalism," in Ethical Theory and Business, 3d ed. T.L. Beauchamp and N.E. Bowie, eds. Englewood Cliffs, NJ: Prentice Hall, 75-93.

Ferrell, O.C., Tracy L. Gonzalez-Padron, G. Tomas M. Hult, and Isabelle Maignan (2010), "From Market Orientation to Stakeholder Orientation," Journal of Public Policy \& Marketing, 29 (Spring), 93-96.

Freeman, R. Edward (1984), Strategic Management: A Stakeholder Approach. Boston: Pitman.

(1999), "Response: Divergent Stakeholder Theory," Academy of Management Review, 24 (April), 233-36.

, Jeffrey S. Harrison, and Andrew C. Wicks (2007), Managing for Stakeholders: Survival, Reputation, and Success. New Haven, CT: Yale University Press. 
- - - - Bidhan L. Parmar, and Simone de Colle (2010), Stakeholder Theory: The State of the Art. Cambridge, MA: Cambridge University Press.

—, Andrew C. Wicks, and Bidhan L. Parmar (2004), "Stakeholder Theory and the Corporate Objective Revisited," Organization Science, 15 (May-June), 364-69.

Godfrey, Paul C., Craig B. Merrill, and Jared M. Hansen (2009), "The Relationship Between Corporate Social Responsibility and Shareholder Value: An Empirical Test of the Risk Management Hypothesis," Strategic Management Journal, 30 (4), 425-45.

Gundlach, Gregory and William L. Wilkie (2010), "Stakeholder Marketing: Why 'Stakeholder' Was Omitted from the American Marketing Association's Official 2007 Definition of Marketing and Why the Future Is Bright for Stakeholder Marketing," Journal of Public Policy \& Marketing, 29 (Spring), 89-92.

Handy, Charles (2002), "What's a Business For?" Harvard Business Review, 80 (December), 49-55.

Hoeffler, Steve, Paul N. Bloom, and Kevin Lane Keller (2010), "Understanding Stakeholder Responses to Corporate Citizenship Initiatives: Managerial Guidelines and Research Direction," Journal of Public Policy \& Marketing, 29 (Spring), $78-88$.

Ingenbleek, Paul T.M. and Victor M. Immink (2010), "Managing Conflicting Stakeholder Interests: An Exploratory Case Analysis of the Formulation of Corporate Social Responsibility Standards in the Netherlands," Journal of Public Policy \& Marketing, 29 (Spring), 52-65.

Isidore, Chris (2010), “Toyota Recall Cost: \$2 Billion" CNNMoney, (February 4), [available at http://money.cnn.com/2010/ 02/04/news/companies/toyota_earnings.cnnw/].

Jawahar, I.M. and Gary L. McLaughlin (2001), "Toward a Descriptive Stakeholder Theory: An Organizational Life Cycle Approach," Academy of Management, 26 (3), 397-414.

Jones, Thomas (1995), "Instrumental Stakeholder Theory: A Synthesis of Ethics and Economics," Academy of Management Review, 20 (2), 404-437.

Kotler, Philip and Gary Armstrong (2010), Principles of Marketing, 13th ed. Upper Saddle River, NJ: Pearson/Prentice Hall.

Laczniak, Gene R. and Ann-Marie Kennedy (2011), "Hyper Norms: Searching for a Global Code of Conduct," Journal of Macromarketing, 31 (September), 12-24.

_ and Patrick E. Murphy (1993), Ethical Marketing Decisions: The Higher Road. Needham Heights, MA: Allyn \& Bacon.

- and (2006), "Normative Perspectives for Ethical and Socially Responsible Marketing," Journal of Macromarketing, 26 (December), 154-77.

— and - (2008), "Distributive Justice: Pressing Questions, Emerging Directions, and the Promise of Rawlsian Analysis," Journal of Macromarketing, 28 (March), 5-11.

Laplume, André O., Karan Sonpar, and Reginald A. Litz (2008), "Stakeholder Theory: Reviewing a Theory That Moves Us," Journal of Management, 34 (6), 1152-89.

Lindfelt, Lise-Lotte and Jan-Åke Törnroos (2006), "Ethics and Value Creation in Business Research: Comparing Two Approaches," European Journal of Marketing, 40 (3/4), 328-51.

Liveris, Andew N. (2010), "Ethics as a Business Strategy," monograph, Raytheon Leadership in Business Ethics, Bentley University, (November).
Lusch, Robert F. and Frederick E. Webster Jr. (2011), “A Stakeholder-Unifying, Co-Creation Philosophy for Marketing," Journal of Macromarketing, 31 (June), 129-34.

Maignan, Isabelle, O.C. Ferrell, and Linda Ferrell (2005), “A Stakeholder Model for Implementing Social Responsibility in Marketing," European Journal of Marketing, 39 (9/10), 956-77.

Marens, Richard (2010), "Speaking Platitudes to Power: Observing American Business Ethics in an Age of Declining Hegemony," Journal of Business Ethics, 94 (2), 239-53.

Martin, Kelly D. and Jean L. Johnson (2010), "Ethical Beliefs and Information Asymmetries in Supplier Relationships," Journal of Public Policy \& Marketing, 29 (Spring), 38-51.

Mick, David (2007), "The End(s) of Marketing and the Neglect of Moral Responsibility by the American Marketing Association," Journal of Public Policy \& Marketing, 26 (Fall), 289-92.

Mish, Jenny and Debra L. Scammon (2010), "Principle-Based Stakeholder Marketing: Insights from Private Triple-BottomLine Firms," Journal of Public Policy \& Marketing, 29 (Spring), 12-26.

Mitchell, Ronald K., Bradley B. Agle, and Donna Wood (1997), "Toward a Theory of Stakeholder Identification and Salience: Defining the Principle of Who Really Counts," Academy of Management Review, 22 (4), 853-56.

Olaniran, Bolanle A., Juliann C. Scholl, David E. Williams, and Lori Boyer (2012), "Johnson and Johnson Phantom Recall: A Fall from Grace or a Re-Visit of the Ghost of the Past," Public Relations Review, 28 (1), 1-3.

Phillips, Robert (2003), Stakeholder Theory and Organizational Ethics. San Francisco: Berrett-Koehler.

Post, James E., Lee E. Preston, and Sybille Sachs (2002), Redefining the Corporation: Stakeholder Management and Organizational Wealth. Stanford, CA: Stanford University Press.

Raghubir, Priya, John Roberts, Katherine N. Lemon, and Russell S. Winer (2010), "Why, When, and How Should the Effect of Marketing Be Measured? A Stakeholder Perspective for Corporate Social Responsibility Metrics," Journal of Public Policy \& Marketing, 29 (Spring), 66-77.

Rawls, John (1971), A Theory of Justice. Cambridge, MA: Harvard University Press.

Rowley, Timothy J. (1997), "Moving Beyond Dyadic Ties: A Network Theory of Stakeholder Influences," Academy of Management Review, 22 (October), 887-910.

Sheth, Jagdish, Raj Sisodia, and David B. Wolfe (2007), Firms of Endearment. Upper Saddle River, NJ: Wharton School Publishing.

Smith, N. Craig, Minette E. Drumwright, and Mary C. Gentile (2010), "The New Marketing Myopia," Journal of Public Policy \& Marketing, 29 (Spring), 4-11.

Stiglitz, Joseph (2010), "Needed: A New Economic Paradigm," Financial Times, (August 20), 7.

Svendsen, Ann (1998), The Stakeholder Strategy: Profiting from Collaborative Business Relationships. San Francisco: BarrettKoehler Publishers.

_ and M. Laberge (2006), "A New Direction for CSR: Engaging Networks for Whole System Change," in The Challenge of Organizing and Implementing Corporate Social Responsibility, J. Jonker and M. deWitte, eds. Basingstoke, UK: Palgrave Macmillan. 
Vargo, Stephen L. and Robert F. Lusch (2004), "Evolving to a New Dominant Logic for Marketing," Journal of Marketing, 68 (January), 1-17.

_ and - (2008), "Service-Dominant Logic: Continuing the Evolution," Journal of the Academy of Marketing Science, 36 (Spring), 1-10.

Waddock, Sandra (2005), Leading Corporate Citizens: Vision, Values and Value Added. New York: McGraw-Hill.

Werhane, Patricia H. (2012), "Decentering Stakeholder Models," in Stakeholder Theory After 25 Years, R. Phillips, ed. Cheltenham, UK: Edward Elgar Publishing.
Wilkie, William L. and Elizabeth S. Moore (2003), "Scholarly Research in Marketing: Exploring the '4 Eras' of Thought Development," Journal of Public Policy \& Marketing, 22 (Fall), 116-46.

and - (2006), "Macromarketing as a Pillar of Marketing Thought," Journal of Macromarketing, 26 (December), 224-32.

Wilson, Scott and Joel Achenbach (2010), "BP Agrees to \$20 Billion Fund for Gulf Oil Spill Claims," The Washington Post, (June 17), [available at http://www.washingtonpost.com/ wp-dyn/content/article/2010/06/16/AR2010061602614.html]. 
Copyright of Journal of Public Policy \& Marketing is the property of American Marketing Association and its content may not be copied or emailed to multiple sites or posted to a listserv without the copyright holder's express written permission. However, users may print, download, or email articles for individual use. 